Author's reply: I thank Katz et al for their insightful comments on this complex topic. I am familiar with their work but, as they suspected, unfortunately removed their 2004 reference from the final version of my editorial because of space restrictions imposed by the Journal. In fact, I reluctantly removed an entire section concerning the value of predicting improvement based on early response in certain psychopathological domains. Katz et al appear to be one of the few groups to examine the issue of differential response in various domains in sufficient detail (Farabaugh et al, 2005). As they recognise, the purpose of an editorial is not to provide an exhaustive review but a synopsis of studies of outstanding interest. Since submitting this editorial a year ago, colleagues and I have nearly completed a more thorough review of this topic, including the work of the San Antonio group and the parallel research that challenges the delayed onset of antipsychotics (Agid et al 2003). I would very much welcome readers' observations regarding the rapidity and measurement of onset of action of mood stabilisers and electroconvulsive therapy, which have received relatively little attention to date.

Agid, O., Kapur, S., Arenovich, T., et al (2003) Delayed-onset hypothesis of antipsychotic action: a hypothesis tested and rejected. Archives of General Psychiatry, 60, 1228-1235.

Farabaugh, A., Mischoulon, D., Fava, M., et al (2005) The relationship between early changes in the HAMD 17 anxiety/somatization factor items and treatment outcome among depressed outpatients. International Clinical Psychopharmacology, 20, 87-91.

Katz, M. M., Tekell, J. L., Bowden, C. L., et al (2004) Onset and early behavioral effects of pharmacologically different antidepressants and placebo in depression. Neuropsychopharmacology, 29, 566-579.

A. J. Mitchell Department of Liaison Psychiatry, Brandon Unit, Leicester General Hospital, Leicester LE5 4PW, UK. E-mail: alex.mitchell@leicspart.nhs.uk

\section{Psychotropic complementary medicines}

The recent review by Werneke et al (2006) contains substantive errors and omissions regarding the iboga alkaloid ibogaine and its synthetic congener 18-methoxycoronaridine (18-MC). The review cites a single paper published in 1994 consisting of seven case reports and overlooks two larger studies on the use of ibogaine for the treatment of opioid withdrawal in 32 (Mash et al, 2001) and 33 patients (Alper et al,
1999). These were retrieved on Medline using the search terms stated by Werneke et al. The authors incorrectly state that clinical trials of ibogaine were abandoned because of cerebellar toxicity: this has been limited to the rat at higher doses than those that diminish drug self-administration and opioid withdrawal, and has not been evident in primate or mouse models (Alper, 2001). In 1993 the US Food and Drug Administration authorised Phase I clinical studies in which humans were given ibogaine. These studies were halted only because of a contractual dispute among the study sponsors and not because of safety issues.

Table 6 of Werneke et al's review states that '18-MC binds to the NMDA [Nmethyl-D-aspartate] receptor' and that this is because of its putative anti-addictive mechanism of action. Mash et al (1995) is cited but this paper makes no mention of 18-MC, which lacks significant affinity for the NMDA receptor but is a potent antagonist at the $\alpha_{3} \beta_{4}$ nicotinic receptor (Maisonneuve \& Glick, 2003). The statement that ibogaine blocks 'the dopamine response in general' is inaccurate, as ibogaine does not have the properties of a dopamine receptor antagonist and does not decrease dopamine release in all brain regions (Maisonneuve et al, 1991).

Werneke et al stated that 'All recovered papers were reviewed for further relevant references', which would have led, among other sources, to an entire volume devoted to ibogaine of the Medline-indexed serial The Alkaloids (Alper \& Cordell, 2001) and the additional references cited here. Systematic implementation of the stated search strategy and careful and accurate reading of the papers that were retrieved would have provided a far more credible evidence basis regarding the use of iboga alkaloids for the pharmacotherapy of addiction.

Alper, K. R. (200I) lbogaine: a review. Alkaloids Chemistry and Biology, 56, I-38.

Alper, K. R. \& Cordell, G. (eds) (200I) Ibogaine: Proceedings from the First International Conference. San Diego, CA: Academic Press.

Alper, K. R., Lotsof, H. S., Frenken, G. M., et al (1999) Treatment of acute opioid withdrawal with ibogaine. American Journal of Addiction, 8, 234-242.

Maisonneuve, I. M. \& Glick, S. D. (2003) Antiaddictive actions of an iboga alkaloid congener: a novel mechanism for a novel treatment. Pharmacology, Biochemistry and Behavior, 75, 607-618.

Maisonneuve, I. M., Keller, R. W. \& Glick, S. D. (1991) Interactions between ibogaine, a potential anti-addictive agent, and morphine: an in vivo microdialysis study. European Journal of Pharmacology, 199, 35-42.

Mash, D. C., Staley, J. K., Pablo, J. P., et al (1995) Properties of ibogaine and its principal metabolite (12-hydroxyibogamine) at the MK-80I binding site of the NMDA receptor complex. Neuroscience Letters, 192 $53-56$

Mash, D. C., Kovera, C. A., Pablo, J., et al (200I)

Ibogaine in the treatment of heroin withdrawal. Alkaloids - Chemistry and Biology, 56, I55-17I.

Werneke, U., Turner, T. \& Priebe, S. (2006)

Complementary medicines in psychiatry. Review of effectiveness and safety. British Journal of Psychiatry, 188 |09-12|.

K. R. Alper Departments of Psychiatry and Neurology, New York University School of Medicine, New York, NY 10016, USA. E-mail: kral@nyu.edu

S. D. Glick Center for Neuropharmacology and Neuroscience, Albany Medical College, Albany, New York, USA

Author's reply: Iboga research remains controversial (Vastag, 2005). Alper \& Glick refer to clinical evidence from 'two larger studies'. However, in these papers it is acknowledged that there is no substantial properly conducted trial available. These studies are difficult to interpret and mainly report treatment of acute opiate detoxification - not the topic of our review. It remains unclear how the patients were selected from the sampling frame. The first series includes a subset of 33 patients treated in hotel rooms or apartments in the USA and The Netherlands between 1962 and 1963 and 1989 and 1993 respectively (Alper et al, 1999). These are referred to as case reports in our review. The second series of 32 patients was equally difficult to rate. Thirty-two patients were treated in a private facility in 'offshore studies' but substantially more patients may have been treated (Vastag 2005) and information on inclusion and exclusion criteria for the individual patients is not available. In an evidence-based review, this would be difficult to accept. For instance, in meta-analyses of randomised controlled trials, open-label trials would not be included even if they were positive. With regard to longer-term abstinence, Mash et al (2001) suggested that 'many' patients were successful but the supporting data were not presented. Notably, in a series of 27 patients, possibly a subset of the 32 , reported 1 year earlier, longerterm outcomes were not presented either (Mash et al, 2000).

With regard to safety concerns, cerebellar degeneration has been reported in 